\title{
The Reason Analysis for the Four Major Mines Contrarian Expansion in Recent Period
}

\author{
Lin $\mathrm{Gu}$ \\ Faculty of Land Resource Engineering, Kunming \\ University of Science and Technology, \\ Kunming, China \\ 956703065@qq.com
}

\author{
Jingtao $\mathrm{Li}^{*}$ \\ Faculty of Information Engineering and Automation, \\ Kunming University of Science and Technology, \\ Kunming, China \\ 446794277@qq.com
}

\begin{abstract}
The iron ore prices continue to fall, but the four major mines contrarian expand their yield, which worsens the unfavorable situation that includes the over-high import dependency of China's iron ore and the import source overconcentrated and increases the operating risks to relevant industry in China. This paper is based on the theory of economic monopoly competition equilibrium to analyze the causes of the four major mines contrarian expansion action, and then researches the new equilibrium point economic reason that because of the production cost reduction after the market has already attained the equilibrium situation. In the light of the moving trace about the curves of marginal cost and marginal revenue, this paper found a conclusion: if the costs reduce, the monopoly competition manufacturers will need to expand their output to maximize the profit. This conclusion is consistent with the fact of the high cost manufacturers are being squeezed out among the four major mines and provides the theoretical basis for the adjustment of the iron ore supply strategy in China.
\end{abstract}

Keywords - Iron Ore Price; Contrarian Expansion; Marginal Cost; Marginal Revenue; Monopoly Competition

\section{INTRODUCTION}

Since 2014, the growth of China's economy development has been slowed down[1]. The weak steel demand and the supply sustaining and rapid increase lead TSI (Fe62\%) to sharply drop $46.1 \%$. After the year 2015 , the iron ore price continues to fall, which has plummet to $\$ 47.1 /$ ton and the index has fallen $28.8 \%$ by the last ten days of July TSI (Fe62\%).

According to public information, four global mining giants of vale, Rio Tinto, BHP Billiton, and FMG (hereinafter referred to as the four major mines), while the iron ore prices rapidly decreased, they not only fail to reduce the supply of iron ore, but their production capacities increase. BHP Billiton's yield will reach 290 million tons; vale will attain 450 million tons; and Rio Tinto will break through 260 million tons[2]. From the early stage of public capacity expansion plans, the year 2014-2015 is the production released summit of new capacity. The first nine months of 2014, the four major mines have increased $12 \%$, and the capacity continues to expand[3]. The year 2015 is still the quick release period, and the world's iron ore export growth will exceed $7 \%$.

The export volume of Australia and Brazil accounted for $70.3 \%$ of global exports in 2013. With the high cost of iron ore has been gradually squeezed out, the global iron ore supply is becoming more concentrated. At present, China imported iron ore prices have fallen by $60 \%$ compared with the beginning of 2014, which is lower than the majority of domestic mining, so there are huge number of domestic mining factory operating loss or even shut down. According to survey data from Mysteel in April 2015 show that the rate of operation of 70 samples China's domestic mine was only around $30 \%$, and the trend was continued to down. In the same way, many small and medium-sized mining in Australia must to face with the same problem of the iron ore prices constantly broken their production cost, they have to cut down their costs or suspend production. From June 2013 to September 2014, there were nearly 200 miners to bankrupt in Australia[4]. With the iron ore price continued to fall in 2015, this number would be continued to expand.

The highly monopolized supply situation of iron ore and its price fluctuation intensified increase the difficulty of the steel raw material stock, which not only increase the risk of China's ore and steel industry but also hide many huge troubles of biding up the price, limiting supply, and even cutting down by suppliers.

The inertial release of initial investment is one of the reasons for the increased supply [5], but there is the deeper economy reason for the four major mines contrarian expanding. This paper, which is through a thorough analysis for the reason of the four major mines expanding yield, provides reference to China's iron ore supply strategies, and help the steel factories to avoid high price risks and make better use of the present low price.

\section{Methodology}

\section{A. The equilibrium under Small monopoly}

The so-called small monopoly is that assuming each manufacturer has monopoly position to its brand or its store location[6]. Monopoly competition manufacturers through the principle that marginal benefit equals marginal cost choose their production quantity (Q1), then sell them in the price ( $\mathrm{p} 1$ ) that decided by the demand curve. As show in Fig.1, the sell price is higher than the average cost, so the monopoly manufacturers acquire profit that would attract other manufacturers to enter the market. Following more and more manufacturers swarming into this market, each manufacturer's market occupation share declines, and every demand curve move to the left. Before the demand curve tangent to the average cost curve, enter will not stop. Before monopoly profits of this industry tends to zero, which has the incentives to the new competitors entered the market[7]. 


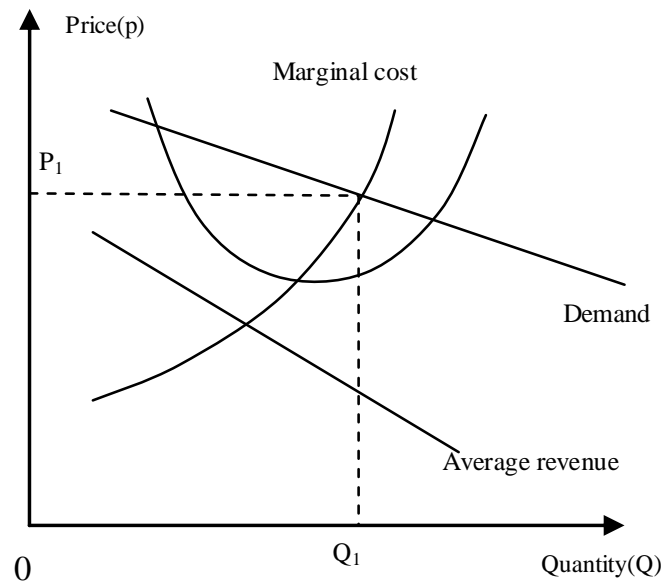

Figure 1. Before the profit maximization of monopoly competition manufacturer

\section{B. The equilibrium under monopoly competition condition}

When the demand curve is just come into contact with the average cost curve, as shown in Fig.2, the point (pe,Qe) presents the monopoly profits is equal to zero. There isn't incentive to urge the new competitors to enter this market. The manufactures' marginal revenue equal to marginal cost, and monopoly competition manufacturers realized the profit maximization. This is because at any other point, the average cost is higher than the price of its demand curve, and profit is negative, only in this point its profit is zero. Correspondingly, the volume Qe is the output of the profit maximization[8].

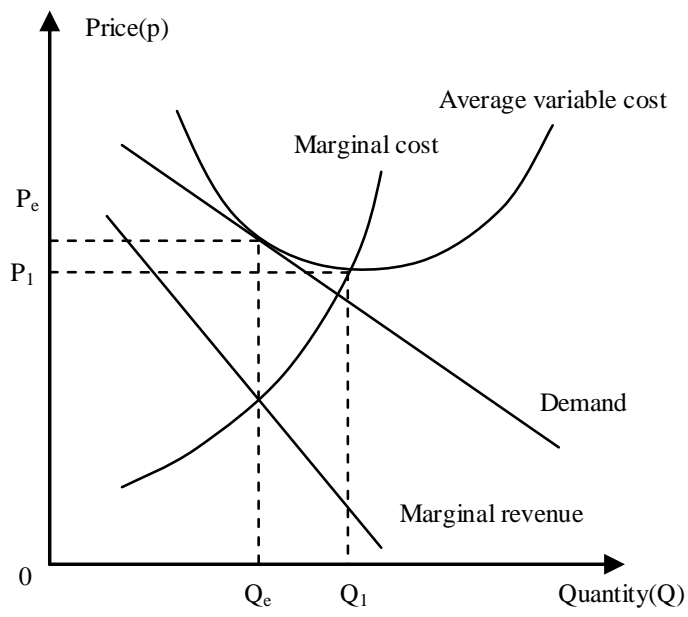

Figure 2. The profit maximization of monopoly competition manufacturer

\section{ASSUMPTION AND DATA ANALYSIS}

Hypothesis under the monopoly competition equilibrium condition, due to the production cost is reducing, so system will be down to look for the new balance point, the early part of the high cost monopoly manufacturer will be squeezed out. As shown in Fig.3, the marginal cost curve $\mathrm{MC}$ move down to the $\mathrm{MC}$, and marginal revenue curve MR move up to MR', (p3,Q3) is a new balance point, obviously Q3 $>$ Q1. That means in this condition, the winning monopoly competition manufacturers must expand their yield to reach profit maximization.

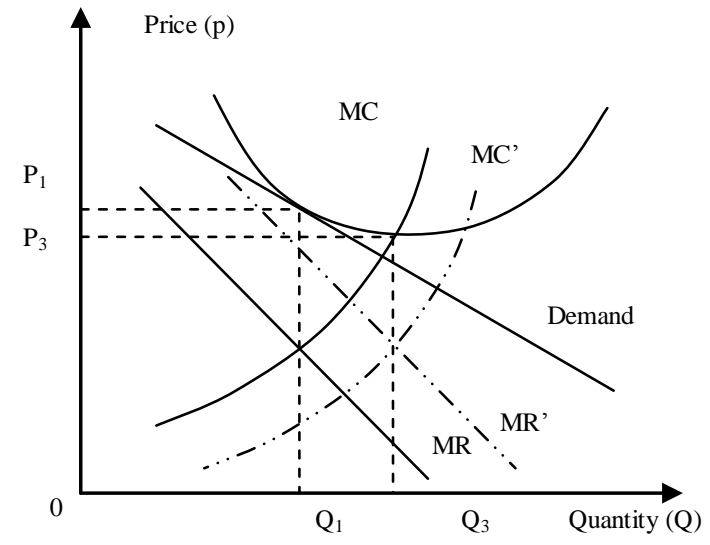

Figure 3. Adjusted profit maximization of monopoly competition manufacturer

FMG's cash cost is the highest among the four major mines, and its competitive position is the last one. The offshore cost of Vale, Rio Tinto, BHP Billiton and FMG in 2014 was \$26.9/ton, \$44.6/ton, \$46.4/ton, \$59.4/ton respectively. FMG's CFI (Cost Insurance and Freight) was declined to $\$ 43.7 /$ ton in the first season 2015 , which is similar to the iron ore's market price. Because the falling iron ore price has been close to FMG's production costs, its profit margins are squeezed severely, then FMG had to declare stopping expanding, and appealing to other three mines limit production to protect price, but Vale, Rio Tinto, BHP Billiton didn't reduce their output on the contrary all of them increase it.

Iron ore is sustaining in low price, the huge low-cost mines that has not fully development in early period are gradually developed[9]. FMG's cost is relatively high, so its market share is impacted by three other mines. Except FMG, other main mines' capacities are sustained to expand, which goes all the way of the economic theory in this paper we've discussed. Although the capacities of Vale, Rio Tinto, and BHP Billiton are increasing, they have not added extra investment plan since last year. Rio Tinto, BHP Billiton will continue to release their additional capacity in the next two years, both of them has not pronounced new expanding projects. Besides the S11D project, Vale doesn't have other expanding plans too[10]. There is no big long-term investment for new capacity in recent year, but the new adding capacities are gradually releasing[11], the supply volume will continue to increase in the next 1-2 years, and the increment of iron ore demand is limited, so its price will keep drifting lower for a long time.

\section{RESULTS AND DISCUSSION}

Expanding the industry scale can reduce the unit cost further, and increasing the output can deprive other highcost mine's market share to dissolve parts of pressure from the downward on prices, so expanding yield is the unanimous selection to the main low cost mines. A large number of low-cost iron ore supply increase will help to decrease the cost of iron and steel production in China, but 
there are many potential huge risks and hidden troubles to China steel industry.

TABLE 1.THE HOLDINGS PROPORTION OF MAJOR IRON ORE MINING FINANCIAL CAPITAL

\begin{tabular}{|c|c|c|c|c|c|}
\hline & HSBC & $\begin{array}{c}\text { JPMorgan } \\
\text { Chase }\end{array}$ & Citibank & $\begin{array}{c}\text { France } \\
\text { Porib }\end{array}$ & others \\
\hline Rio Tinto & $21.4 \%$ & $16.5 \%$ & $6.6 \%$ & $4 \%$ & $51.4 \%$ \\
\hline $\begin{array}{c}\text { BHP } \\
\text { Billiton }\end{array}$ & $17.8 \%$ & $15.4 \%$ & $10.8 \%$ & $2.5 \%$ & $53.4 \%$ \\
\hline & $\begin{array}{c}\text { Mitsui } \\
\text { Group }\end{array}$ & $\begin{array}{c}\text { Brazil's } \\
\text { pension }\end{array}$ & institutional investor & others & \\
\hline Vale & 18.2 & $49 \%$ & $21.2 \%$ & $11.6 \%$ & \\
\hline
\end{tabular}

\section{A. High external dependency}

As iron ore prices will keep in low, low cost of import ore replace the high cost of domestic ore is an irreversible trend in recently, so China will keep high external dependency and even the value of it may be higher than now. Nearly $80 \%$ China's iron ore supply needs to import, if the value increases further, that means more than $80 \%$ production raw material was hold by the foreign country, which will bring huge risk for China's steel industry.

\section{B. The import source location is over-concentrated}

China's iron ore imports come from more than 30 countries and regions, Australia, Brazil, and India are the main import source, and the import amount from this four country account for $76.5 \%-95.8 \%$. Recently, for the purpose of protecting the domestic mine resource and priority to guarantee its domestic production demand, India government has increased the export tariff and limited export since 2011, so the import proportion from India has decreased, the proportion is less than $1 \%$ in 2014. The proportion of iron ore imports from Australia, Brazil, and South Africa has accounted for $82.64 \%$ of total imports, and the proportion from Australia is obviously rising which has reached 58.8 in 2014. Due to scale effect and mining enterprises implement the cost-saving and profit-increasing strategy, Australian mine exploiting cost is gradually reducing. Rio Tinto group has declared in public in 2014, its exploiting cost has fallen to less than $\$ 18 /$ ton. So the amount of China's iron ore imports from Australia is likely to continue to increase, then the import proportion from Australian will continue to improve. China's iron ore resource nearly $60 \%$ will be controlled by Australia, and even nearly $80 \%$ or more China's iron ore resource will be controlled by the four major mines.

Iron ore is no longer as a simple production raw material, its financial attributes is appearing gradually, each giant mines has firmly controlled by financial capital, as shown in Table 1. A few years ago the surge of iron ore prices, the huge financial capital is the main driving force. At present, the political situation is relatively stable, and the main risk from the import resource over-concentrated is the iron ore price manipulation by the giant financial capital. If the political situation becomes broken suddenly in the future, the relative governments limit their exports to China, then China's steel industry will face with supply interruption which may lead to the steel factory production halt and even many of downstream industry stop too. That must bring detriment to social stability in the country.

\section{Domestic mines being squeezed out}

Due to the limit from exploiting technology and the natural resource shortage in current stage, China's production cost is much higher the four major mines, so a lot of domestic mines were forced to withdraw from the market. Following low cost of iron ore continue to seize domestic market, there will be much more national mines to be repelled, which will lead to a dramatic number of works loss job and even threaten the social stable. Meanwhile, the reduction of domestic supply will push up external dependency, and increase the interruption risks.

\section{POLICY IMPLICATIONS}

It is difficult for domestic iron ore to support the large demand of China's steel production, so China has to purchase a large number of imported iron ore to satisfy the production requirements of country's steel industry. It is is difficult to reberse the situation of China's iron ore high external dependency and import source over-concentrated in short time. The Chinese government should pay abundant attention to the serious supply situation and enact a reasonable iron ore supply strategy to fit the present economic development stage.

\section{REFERENCES}

[1] Guan,R.R.,Zhang,D.H.,Chen,Q.S., China's iron ore demand analysis, J. China's mining industry.(2011) 20(4):28-31.

[2] [2]Shi,J.P., The development of Chinese small and medium-sized enterprise financial services report, M. China Financial Publishing House. (2013)2-6.

[3] [3] Xiong,X.H., A seller's market monopoly under the condition of the international iron ore price formation mechanism research, $\mathrm{J}$. Foreign trade.(2013) 23-26.

[4] [4] Xu,G.Q., Present situation and the development of Australian iron ore industry, J. World Iron \& Steel.(2011) 68-72.

[5] [5] Wang,W.C.,Hou,T., Yang,Y.D., The grey system theory in the application of China's iron ore consumption and imports, J. Journal of Inner Mongolia university of science and technology.(2011) 193-195

[6] [6]Paul,C., Forecasting steel consumption in South-East Asia, J. Resources Policy(1999) 111-123.

[7] [7]Mark,E., Steel consumption and economic activity in the UK The integration and cointegration debate, J. Resources Policy, (2011) 97-106.

[8] [8]Lian,p., China's banking sector review and prospect, J. Financier(2014) 44-49.

[9] [9]Ma,S.H.,Wen,Z.G.,Chen,J.n.,Wen,Z.C., Mode of circular economy in China's iron and steel industry: a case study in Wu'an city, J. Journal of Cleaner Production.(2014), 505-512.

[10] [10]Xiang,Y.,Chen,W.Y., Trends and development of steel demand in China: A bottom-up analysis, J. Resources Policy.(2013) 407 415.

[11] [11]WU,J.Q., Import iron ore price forecasting based on PSOSVMs model, J. Computer Science \& Education.(2012) 14-17.

[12] Liu Feng. A research on risk assessment of foreign mineral resources exploitation and selection [D]. Changsha: Zhongnan University, 2009.

[13] Li Kui-xing. A brief discussion on risk management of mining investment [J]. China Mining, 2009,18, (12)

[14] Ren Jie. A research on risk assessment and real option of investing overseas mineral resources project [D]. Beijing: China University of Geosciences (Beijing),2014. 
[15] Xie Lin-lin. A research on decision-making mechanism of public investment and construction project [D]. Chongqing: Chongqing University, 2005.

Tian Ze. A research on risk assessment of overseas investment of Chinese companies [J]. Inquiring into Modern Economy, 2013 (11)
[16] Cheng Jin-hua, Sheng Tong. An analysis on political risks in transnational operation of Chinese oil company [J]. China Soft Science, 2006 (4) 